\title{
Biosynthetic cellulose induces the formation of a neoduramater following pre- natal correction of meningomyelocele in fetal sheep ${ }^{1}$
}

\author{
A celulose biossintética induz a formação de uma neoduramáter na correção antenatal \\ da meningomielocele em fetos de ovelhas
}

\author{
Rita de Cássia Sanchez e Oliveira², Paulo Roberto Valente ${ }^{3}$, Rogério C. Abou-Jamra ${ }^{4}$, Andrezza Araújo ${ }^{5}$, Paulo \\ Hilário Saldiva ${ }^{6}$, Denise Araújo Lapa Pedreira ${ }^{7}$ \\ 1. Study performed at Experimental Surgery Unit of Dante Pazzanese Institute of Cardiology and Pathology Department of Faculty of Medicine, \\ University of São Paulo (FMUSP), Brazil. \\ 2. Fellow PhD degree, Pathology Department, FMUSP, Brazil. \\ 3. Veterinarian, Chief of Experimental Surgery Unit, Dante Pazzanese Institute of Cardiology, São Paulo, Brazil. \\ 4. Fellow Master degree, Experimental Physiopathology Department, FMUSP, Brazil. \\ 5. Veterinarian, Experimental Surgery Unit, Dante Pazzanese Institute of Cardiology, São Paulo, Brazil. \\ 6. Chairman, Pathology Division, FMUSP, Brazil. \\ 7. PhD, Head of Fetal Medicine Team of Albert Einstein Hospital, São Paulo, Brazil.
}

\begin{abstract}
Purpose: The aim of this study was to compare the effectiveness of two dura-mater substitutes, namely human acellular dermal matrix (HADM) and biosynthetic cellulose (BC), in repairing, in utero, surgically-induced meningomyelocele (MMC) in fetal sheep. Methods: A neural tube defect was created at 74-77 days gestation in 36 fetal sheep. They were divided into 3 groups, the control group that did not receive pre-natal corrective surgery, and the other two groups that received corrective surgery using HADM (Group A) or BC (Group B). Both materials were used as a dura-mater substitutes between the neural tissue and the sutured skin. Correction was performed at gestation day 100 and the fetuses were maintained in utero until term. Sheep were sacrificed on gestation day 140. The fetal spine was submitted to macro and microscopic analysis. At microscopy, adherence of the material to the skin and neural tissue was analyzed. Results: In the initial phase (pilot), experimentally-induced MMC was performed on 11 fetuses and 4 survived (37\%). In the second phase (study), 25 fetuses received surgery and 17 survived (68\%). In the study group, 6 fetuses did not undergo repair (control group), 11 cases were submitted to corrective surgery (experimental group) and one fetal loss occurred. Of the surviving cases in the experimental group, 4 constituted Group A and 6 in Group B. Macroscopically, skin and underlying tissues where easily displaced from the $\mathrm{BC}$ in all cases it was used; in contrast, HADM adhered to these tissues. To compare the adherence, 4 cases from Group A and 4 in Group B were studied. We observed adherence, host cell migration and vessel proliferation into the HADM all sections from Group A and this aspect was not present in any cases in Group B (p < 0.05). In Group B, we also observed that a new fibroblast layer formed around the BC thus protecting the medulla and constituting a "neoduramater". Conclusion: The use of BC seems to be more adequate as a dura-mater substitute to cover the damaged neural tissue than HADM. It seems promising for use in the in utero correction of MMC because to does not adhere to neural tissue of superficial and deep layers ("tethered spinal cord"). Thus, BC minimizes the mechanical and chemical intrauterine damage to the spinal medulla.
\end{abstract}

Key words: Fetus. Meningomyelocele. Spinal dysraphism. Prenatal care. Cellulose. Animal experimentation. Sheep.

\section{RESUMO}

Objetivo: Estudar os efeitos do emprego de dois materiais consideravelmente diferentes quanto à origem e custo na correção intra-uterina da meningomielocele criada experimentalmente em feto de ovino. Métodos: Em 36 fetos de ovinos foi criado um defeito aberto de tubo neural, com 75 de dias de gestação. Os casos foram divididos em três grupos: o controle onde o defeito não foi corrigido, grupo corrigido A onde o material utilizado para cobrir a medula exposta foi a matriz dérmica humana acelular (MDHA) e o grupo corrigido B onde o material foi a celulose biossintética (CB). Após a correção realizada com 100 dias, os fetos eram mantidos intra-útero até o termo da gestação. Os sacrifícios foram realizados com 140 dias e a coluna fetal era submetida à análise macro e microscópica 
onde foi observada a aderência dos materiais à pele, medula ou tecido nervoso remanescente. Resultados: Na fase inicial (piloto), 11 fetos foram operados e 4 sobreviveram (37\%). Na segunda fase (estudo) 25 fetos foram operados e 17 sobreviveram (68\%). No grupo de estudo, 6 fetos não foram submetidos à correção (grupo controle), 11 casos foram corrigidos e ocorreu 1 perda fetal. Do total de 10 casos, 4 constituíram o grupo A e 6, o grupo B. À macroscopia observou-se deslizamento da pele e tecidos subjacentes sobre a CB em todos os casos onde ela foi empregada e isto não ocorreu em nenhum dos casos onde a MDHA foi utilizada. Para comparar a aderência, foram considerados 4 casos do grupo A e 4 do grupo B. A aderência, caracterizada pela migração de células do hospedeiro e proliferação de vasos para dentro da MDHA, foi observada em 100\% dos casos do grupo A e em nenhum caso no grupo B (p < 0,05). No grupo B observou-se formação de uma camada de fibroblastos ao redor do material, protegendo a medula, caracterizando a formação de uma “neoduramater”. Conclusão: A utilização da película de celulose biossintética parece ser mais adequada como substituto de dura-máter para cobertura e proteção do tecido nervoso que a matriz dérmica humana acelular. Ela parece promissora na correção intra-uterina da meningomielocele, evitando a aderência do tecido nervoso aos planos superficiais ("medula presa”) minimizando os efeitos deletérios do ambiente intrauterino sobre a medula espinhal.

Descritores: Feto. Meningomielocele. Disrafismo espinhal. Cuidado pré-natal. Celulose. Experimentação animal. Ovinos.

\section{Introduction}

Spina bifida is a developmental birth defect that is characterized by the failure of the embryonic neural tube to fully close resulting in malformed vertebrae that do completely envelop the spinal cord. ${ }^{1}$ One type of this defect is myelomeningocele (MMC) which has a high incidence in humans (1 to 3 in every 1000 live births) ${ }^{2}$. MMC can be repaired surgically after birth although the success rate varies possibly because of irreparable damage to the spinal cord that occurs pre-natally. Experimental studies suggest that neural tissue may be injured by exposure to chemical (amniotic fluid) and mechanical factors in utero ${ }^{3.4}$. Thus, despite post-natal corrective surgery, a high degree of sequelae can persist, including motor deficiency, urinary and fecal incontinence, cerebellar herniation leading to a hydrocephalus and mental retardation ${ }^{5}$. Furthermore, neurosurgery at birth can not correct the "tethered cord syndrome” caused by adhesion between neural tissue and skin $^{6}$. Since post-natal surgery does not reverse previous neurological damage in utero, operating pre-natally may be more effective. In support of this, studies have shown that in utero repair can prevent or reverse the ArnoldChiari malformation and hydrocephalus, minimizing post-natal sequelae ${ }^{7-10}$. Several materials have been used as dura-mater substitutes in MMC corrective surgeries that have different origins, manufacture, costs and handling. One such material is the human acellular dermal matrix (HADM) which is a regenerative tissue matrix that has been used in craniotomies and adult spinal cord lesions ${ }^{11}$. It has also been applied as a visceral protection in cases of giant newborn omphalocele ${ }^{12}$. HADM is considered a good alternative if an allograft is not available and it is as pliable as a dura-mater patch intra-operatively. It does not induce adhesions or rejections, although fluid leakage through the material occurred in a few cases ${ }^{11}$. Paek et al. $(2000)^{13}$ studied the effects of HADM in ovine models, applied above
MMC as a patch and sutured to the skin. This author observed wound contraction and skin growth over the HADM, preventing posterior herniation of the cerebellum, compared to uncovered controls. Another material experimental dura-mater substitute is biosynthetic cellulose $(\mathrm{BC})^{14,15}$. This Brazilian manufactured membrane is a low-cost material that has been used in plastic surgery as a temporary skin substitute for second degree burns. BC has been used during corrective surgery to cover the exposed spinal cord in a fetal rabbit model and showed no signs of rejection ${ }^{16}$. The aim of this study is to compare the effectiveness of HADM and BC in protecting neural tissue after in utero surgery to correct experimentallyinduced MMC in a fetal ovine model. Sheep were chosen for the experimental animal since they are used widely in experimental studies of gestation and fetal surgery, mainly because both its size and anatomy are similar to the human fetus. Furthermore, sheep can be easily handled in pen, have a small number of fetuses (1 or 2 ) and a low rate of premature labor ${ }^{1}$.

\section{Methods}

Thirty three mixed breed Hampshire Down sheep were obtained from a single breeder. Pregnancy was dated from intra-cervical insemination, during the natural estrous (twice a year). Three of them were twin pregnancies, so a total of 36 fetuses were studied. The study was approved by Dante Pazzanese Institute Ethics Committee. The animals were transported from farm and given a minimum adaptation period of $4 \mathrm{~d}$. They were maintained in a semi-open pen with natural day/night variation.

\section{Experimentally-induced MMC}

Surgery to induce MMC was performed in all fetuses between 74 and 77 days of gestation. The initial 
phase (pilot group) involved 9 animals, pregnant with 11 fetuses; the second phase (study group) consisted of 25 fetuses. In the corrected group, reparative surgery was performed between 93 and 112 days of gestation. These animals remained in utero for the term of gestation. In the control group the MMC was induced but the correction surgery was not performed. Before surgery, animals were submitted to 48-hour food and 24-h fluid fast. The anesthetic protocol consisted of preanesthetic medication while still in the pen (acepromazine $0.2 \mathrm{mg}$ / $\mathrm{kg}+$ midazolan $-0.3 \mathrm{mg} / \mathrm{kg} \mathrm{IV}$ ), allowing the animal to be transported while sedated. Hair was removed immediately before entering the operating room. Animals were anesthetized with intravenous thiopental $(7.5 \mathrm{mg} /$ $\mathrm{kg}$ ), followed by orotracheal intubation, and then maintained with $2 \%$ halothane. During the operation and post-anesthetic recovery a total of $15 \mathrm{ml} / \mathrm{kg} / \mathrm{hr}$ of $0.9 \%$ saline containing $15 \mathrm{ml} / \mathrm{kg} / \mathrm{h}$ of $50 \%$ glucose. A single dose of the antibiotic prophylaxis enrofloxacin (5 mg/ $\mathrm{kg}$ ) was administered. The animal was positioned in right lateral decubitus, and a left para-mammary laparotomy was used to expose the uterus. A $5 \mathrm{~cm}$ hysterotomy was performed just above the fetal spine allowing back paws and tail exteriorization. The amniotic fluid was then removed $(100 \mathrm{ml})$ and maintained in a heated saline bath to posterior restitution during hysterorrhaphy. The skin resection over lumbosacral spine measured 3.0 x $1.5 \mathrm{~cm}$. Bilateral paravertebral muscles resection and a complete laminectomy of four lumbar vertebrae extensions were performed. Dura-mater was incised with a scalpel, cerebral spinal fluid (CSF) leakage was visualized and the medullar spine was incised to the central canal. The medulla was then left exposed. The fetus was returned to the uterus which was then closed, afterwards by the abdominal maternal wall was sutured in layers. Fetal heart-rate was checked through a transoperative ultrasonography (US) and animals were returned to the pen after spontaneous breathing started. Utero-lytics were not used during or after the procedures.

\section{Corrective surgery for $M M C$}

The corrected cases were divided in two groups according to the material used to cover the neural tissue: Group A received HADM (AlloDerm ${ }^{\mathrm{R}}$, Lifecell, USA) and Group B was given BC (Nexfill ${ }^{\mathrm{R}}$, Brazil; Dermafill ${ }^{\mathrm{R}}$, USA). The same perioperative conditions used for the defect creation were repeated for the corrective procedure up to the point of fetal back exposure. Both materials were applied over the damaged neural tissue according to the previously developed technique used in the fetal rabbit model ${ }^{16}$. Briefly, we under cut $1.0 \mathrm{~cm}$ of the skin beyond the margins of the defect and placed either HADM or BC over the exposed neural tissue and under the skin edges; skin was then approximated to cover all the material (Figure 1). HADM is obtained from human cadaveric skin supplied from tissue banks, processed for epidermal removal with a high ionicstrength solution and dermal separation. Subsequently, cells are removed and the remaining bioactive components and extra cellular matrix (collagen and elastin) are preserved. The result is a foundation for normal revascularization, cell repopulation and tissue remodeling, becoming the patient's own tissue. It is preserved by freeze-drying, needing special storage and lower temperatures for transportation. The manufacturing process is complex and costly $y^{17,18}$. The BC film is produced by Acinetobacter bacteria fermentation using specific technique developed in Brazil, approved by the FDA (USA) in 1995. The cellulose mass is sliced, washed and deproteinated using special solvents. The storage and transportation are at room temperature and it can be reesterilized in ethylene oxide. It has a significantly lower cost compared to HADM. It was developed to protect burn areas or to cover graft donor sites, allowing reepithelization under the material. When the new skin is formed, the BC detaches spontaneously ${ }^{14}$.

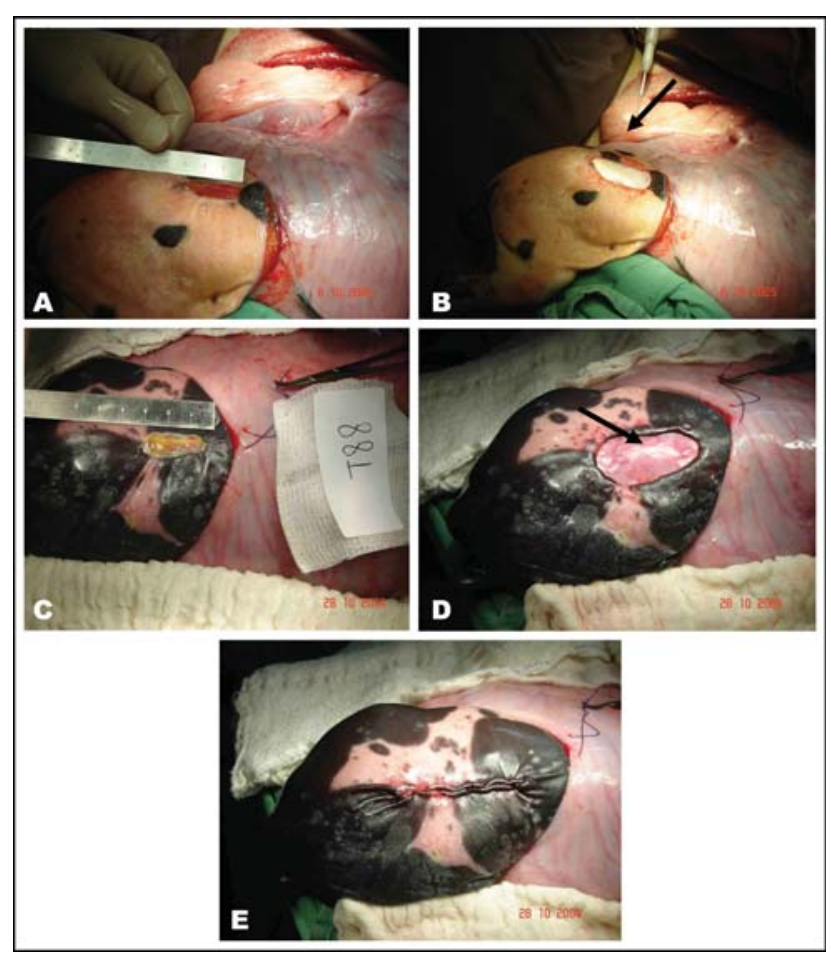

FIGURE 1 - Stages of corrective surgery for experimentallyinduced MMC in sheep fetus. (A) Exposed fetal back during correction surgery at 100 days of gestation. Note the previously created neural tube defect. (B) Human acellular dermal matrix (HADM; black arrow) covering the defect. (C) Same aspect of another animal at 100 days of gestation, with induced MMC. (D) Biosynthetic cellulose (BC; black arrow) was used to cover the defect before it is recovered with skin. (E) Postoperative sutured skin 


\section{Fetal harvesting and macroscopic analysis}

Animals were sacrificed at gestation day 140. The same pre-anesthetic medication was used for maternalfetal sacrifice, but the thiopental dose was increased to $20 \mathrm{mg} / \mathrm{kg}$ to guarantee fetal sedation. After a few minutes, a $19.1 \% \mathrm{KCl}$ bolus was injected into maternal circulation $(0.4 \mathrm{ml} / \mathrm{kg})$. After maternal cardiac arrest, the abdominal wall and uterus were opened. If fetal heart activity was detected a $5 \mathrm{ml} \mathrm{KCl}$ bolus was administered to the fetus. The fetuses were photographed, weighed and submitted to macroscopic and microscopic analysis. The entire fetus was fixed in formalin for $7 \mathrm{~d}$, after a sample of the spine was removed. This specimen incorporated one vertebra above and one below the defect region, along with $3 \mathrm{~cm}$ lateral margins of surrounding tissues, all layers included. To prepare slides, the specimens were incubated for 4 wks in EDTA buffer solution for decalcification. Hematoxilin-Eosin (HE) and Masson staining were performed in a total of five standard sections, containing the whole defect area in both groups (Figure 2). All the samples were analyzed by the same pathologist (PHS). Statistical analysis was carried out at Epidemiology and Statistical Laboratory of Instituto Dante Pazzanese applying the Fisher test, with a 5\% significance level.

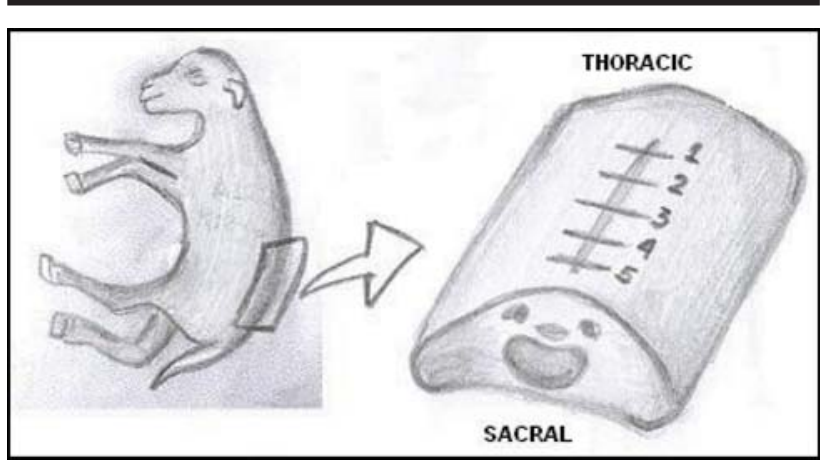

FIGURE 2 - Anatomical planes from which the five tissue sections were made for microscopic analysis, containing all areas of the defect

\section{Microscopical analysis}

The adherence to adjacent tissues was analyzed in both superficial (next to skin) and deep (next to neural tissue) material surfaces. The presence of cells and vessels that invaded from adjacent tissues was evaluated.

\section{Results}

\section{Survival rate and prematurity}

The study was divided into two phases: i) pilot and ii) study. The pilot phase was conducted first and involved standardizing the technique for producing and correcting the MMC defect; a total of 11 fetuses had experimentally-induced MMC. Of this group, 7 fetuses died representing a survival rate of $37 \%$ (Table 1 ). In the study phase, 25 fetuses received MMC and 8 fetal losses occurred. Thus, the survival rate, after the creation of the defect, was $68 \%$. Among the 17 surviving fetuses, 6 did not undergo corrective surgery (control group) and 11 received the reparative operation (corrected group). Of the former group, 2 had premature deliveries; of the corrected cases, 1 fetal loss occurred (9\%) and 2 premature deliveries were observed (Table 2).

\section{Surgically corrected cases}

A total of 10 corrected cases were available for macroscopic and microscopic analysis: 4 cases in Group A that received HADM and 6 cases in Group B that received $\mathrm{BC}$. Macroscopically the skin was completely closed in 1 case in the control group, 2 cases in Group A and 5 cases in Group B. Macroscopically, during dissection, the skin and underlying tissues were easily displaced from the BC in all cases in Group B. In contrast, HADM was firmly adhered to adjacent tissues in Group A.

\section{Microscopical analysis}

In the control group, histological analysis revealed that the medulla was typically exposed and in 4 out of 6 cases was destroyed. Even in cases in which the skin was partially or completely enclosing the defect, the medulla under the skin was damaged. It appeared that the greater the "in utero" exposure, the greater the damage to the neural tissue. Four weeks after the defect creation, erosion extended to the posterior horns; the medullar central canal and anterior horns were preserved ("flat medulla"). If the fetus was remained in utero for 8 weeks, a typical MMC-like defect (total destructive lesion of medulla) was observed. In the corrected group, for comparison purposes, only cases that stayed in utero a minimum of 28 days after correction were used; thus, a total of 4 cases were analyzed in Group A and 4 in Group B. In Group A, all 4 cases showed blood vessel ingrowth from the host tissue to the HADM and the implant was integrated to the skin with no cleavage plane between the animal dermis and the HADM. The same aspect was found where the HADM contacted the medulla. 
TABLE 1 - Gestational age at the time of surgical procedures and follow-up of fetuses that received experimentallyinduced MMC and corrective surgery in the pilot study

\begin{tabular}{|c|c|c|c|c|c|c|}
\hline Pilot & Group & GAC & GACorr & GASacr & Evolution & Macroscopic Analysis \\
\hline 1 & Control & 77 & - & 98 & PS (1) & Open Def 3,0 x 2,5cm \\
\hline 2 & Control & 77 & - & 93 & $\mathrm{PD}$ & Open Def 3,0 x 2,5cm \\
\hline 3 & Control & 74 & - & 107 & $\mathrm{PD}$ & Open Def 4 x 3,5cm \\
\hline 4 & $\mathrm{~B}$ & 75 & 93 & 133 & $\mathrm{PD}$ & Wound healing 70\% \\
\hline 5 & Miscarriage & 73 & - & 80 & IUD & - \\
\hline 6 & Miscarriage & 73 & - & - & $\begin{array}{l}\text { MD+IUD } \\
\text { (transoperative) }\end{array}$ & - \\
\hline 7 & Miscarriage & 72 & - & - & 2po IUD & - \\
\hline 8 & Miscarriage & 75 & - & - & 2po IUD & - \\
\hline 9 & Miscarriage & 73 & - & 80 & IUD & - \\
\hline 10 & B (Miscarriage) & 76 & 92 & 92 & IUD transoperative & - \\
\hline 11 & A (Miscarriage) & 74 & - & 107 & 2po IUD & - \\
\hline $\begin{array}{l}\text { PS - pa } \\
\text { GAC: } \\
\text { GACor } \\
\text { GASac } \\
\text { PD: pre } \\
\text { (1) - sa }\end{array}$ & $\begin{array}{l}\text { hological study } \\
\text { estational age at defec } \\
\text { : gestational age at co } \\
\text { gestational age at ma } \\
\text { mature delivery } \\
\text { crificed to PS analysis }\end{array}$ & $\begin{array}{l}\text { eation } \\
\text { tion } \\
\text { tal-fetal } \\
\text { st anima }\end{array}$ & & \multicolumn{3}{|c|}{$\begin{array}{l}\text { po - pos-operative day } \\
\text { A - Group using HADM } \\
\text { B - Group using BC } \\
\text { Control - Group unrepaired } \\
\text { IUD - Intra Uterine Death } \\
\text { MD - Maternal Death }\end{array}$} \\
\hline
\end{tabular}

TABLE 2 - Gestational age at the time of surgical procedures and follow-up of fetuses that received experimentallyinduced MMC and corrective surgery during the study phase

\begin{tabular}{|c|c|c|c|c|c|c|}
\hline Cases & Group & GAC & GACorr & GASacr & Evolution & Macroscopic analysis \\
\hline 1 & Control & 75 & - & 140 & - & Wound healing 100\% \\
\hline 2 & Control & 75 & - & 139 & - & Open Def 4 x $2 \mathrm{~cm}$ \\
\hline 3 & Control & 75 & - & 139 & - & Wound healing 70\% \\
\hline 4 & Control & 75 & - & 112 & PD & Open Def 3 x 2,5 cm \\
\hline 5 & Control & 75 & - & 111 & PD & Open Def 3 x $2 \mathrm{~cm}$ \\
\hline 6 & Control & 78 & - & 140 & - & Open Def 4 x $1 \mathrm{~cm}$ \\
\hline 7 & Miscarriage & 74 & - & 76 & IUD 2o PO & - \\
\hline 8 & Miscarriage & 75 & - & 76 & IUD1o PO & - \\
\hline 9 & Miscarriage & 75 & - & 76 & IUD & - \\
\hline 10 & Miscarriage & 75 & - & 75 & IUD & - \\
\hline 11 & Miscarriage & 74 & - & 75 & IUD & - \\
\hline 12 & Miscarriage & 77 & - & 90 & IUD & - \\
\hline 13 & Miscarriage & 77 & - & 85 & IUD & - \\
\hline 14 & Miscarriage & 77 & - & 90 & IUD & - \\
\hline 15 & A & 75 & 105 & 138 & - & Wound healing 100\% \\
\hline 16 & A & 75 & 105 & 137 & - & Wound healing 100\% \\
\hline 17 & A & 77 & 105 & 134 & - & Wound healing 70\% \\
\hline 18 & A & 77 & 105 & 138 & - & Wound healing 50\% \\
\hline 19 & B & 75 & 105 & 105 & IUD in correction day & - \\
\hline 20 & $\mathrm{~B}$ & 75 & 103 & 140 & - & Wound healing 100\% \\
\hline 21 & B & 75 & 103 & 118 & PD & Wound healing 70\% \\
\hline 22 & $\mathrm{~B}$ & 74 & 103 & 118 & PD & Wound healing 100\% \\
\hline 23 & $\mathrm{~B}$ & 75 & 97 & 138 & - & Wound healing 100\% \\
\hline 24 & $\mathrm{~B}$ & 75 & 103 & 137 & - & Wound healing 100\% \\
\hline 25 & $\mathrm{~B}$ & 75 & 98 & 126 & PD & Wound healing 100\% \\
\hline $\begin{array}{l}\text { GAC: ge } \\
\text { GACorr: } \\
\text { GASacr: } \\
\text { PD: prem } \\
\text { po - pos- }\end{array}$ & $\begin{array}{l}\text { tional age at defec } \\
\text { stational age at co } \\
\text { stational age at ma } \\
\text { are delivery } \\
\text { erative day }\end{array}$ & $\begin{array}{l}\text { ion } \\
\text { in } \\
\text {-fetal sa }\end{array}$ & & \multicolumn{3}{|c|}{$\begin{array}{l}\text { A - Group using HADM } \\
\text { B - Group using BC } \\
\text { Control - Group unrepaired } \\
\text { IUD - Intra Uterine Death }\end{array}$} \\
\hline
\end{tabular}


Multiple sites of adhesion to neural tissue, bypassing vessels and cell infiltration were also observed (Figure 3). In Group B that received BC during corrective surgery, all 4 cases showed that the BC was completely occupied by a newly formed layer of fibroblasts (Figure 4). This fibroblast layer was in anatomic continuity with the dural margins that form a new cell layer resembling the dura-mater itself, a "neodura-

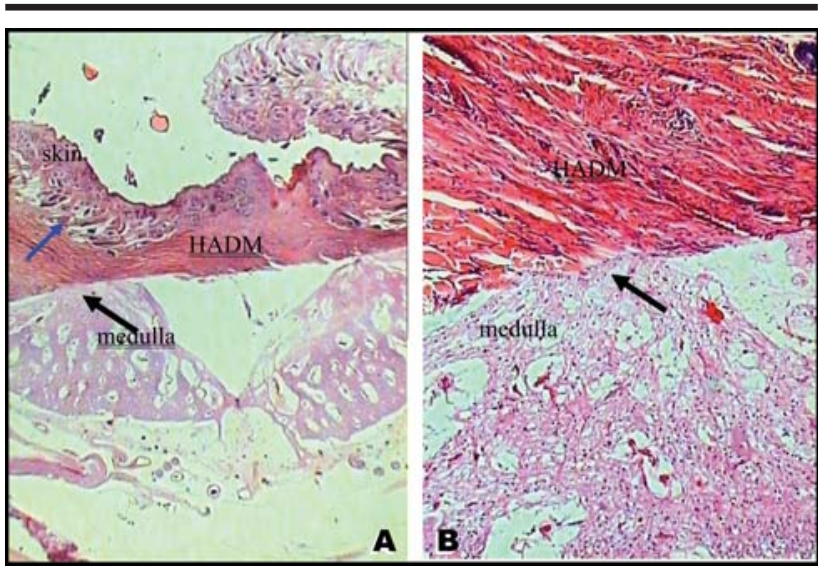

FIGURE 3 - Fetus in Group A that received corrective surgery for experimentally-induced MMC using human acellular dermal matrix (HADM). (A) HADM adhered to the skin (blue arrow) and to neural tissue (black arrow). Hemathoxilin-Eosin stain - 16x. (B) Detailed aspect of the same section shown in panel A. Note the ingrowth of cells from the medulla (black arrow) into the HADM. Hemathoxilin-Eosin stain - 100x

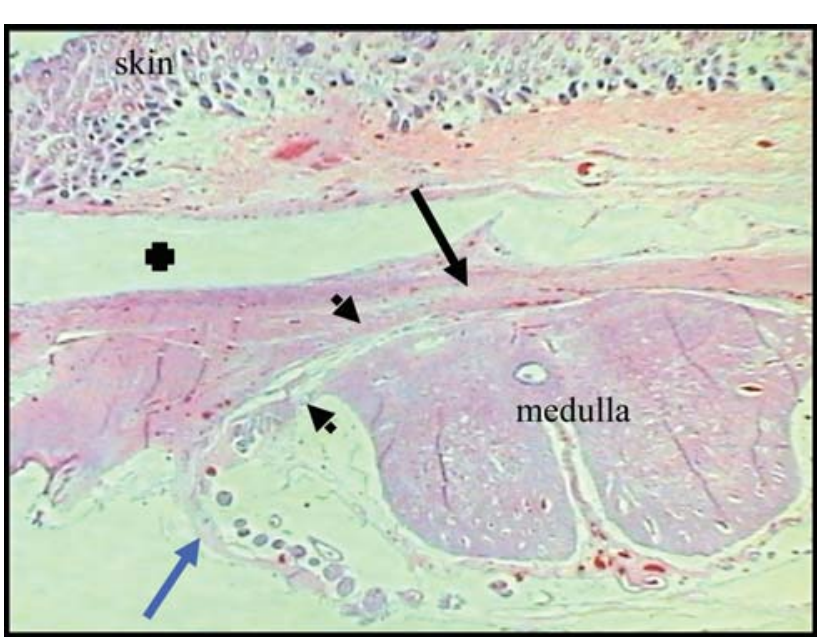

FIGURE 5 - Histological aspects of the "neoduramater" formation. Note the original duramater (blue arrow) in anatomical continuity (arrows heads) with the newly formed fibroblast layer (black arrow) underneath the biosyntetic cellulose (BC; black cross). HemathoxilinEosin stain $-16 \mathrm{x}$ mater” layer (Figure 5). No connective tissue or collagen appeared to have invaded the BC layers. Furthermore, blood vessel proliferation, cell ingrowth and adhesion to surfaces (superficial or deep) were not evident. These characteristics described for Group B were markedly different from those seen in Group A; these group differences were statistically significant ( $p=0.029$; Fisher test).

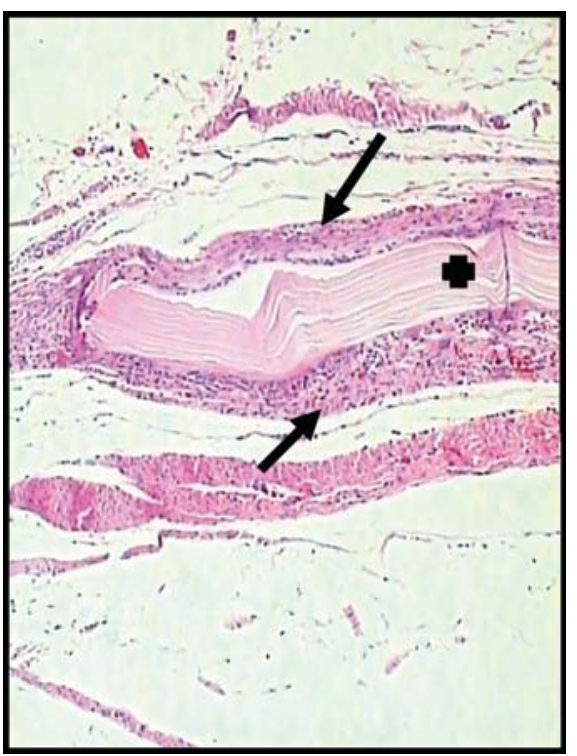

FIGURE 4 - Histological feature of the biosynthetic cellulose (BC; black cross). No ingrowth of cells into the material was observed. Note the fibroblast layer covering the deep and superficial surfaces (black arrows). Hemathoxilin-Eosin stain - 50x

\section{Discussion}

The classical MMC corrective neurosurgery performed at birth involves dissecting tissues adjacent to the defect and suturing the dura-mater to protect the medulla. _Despite these reparative measures, nerve root scarring at the site of MMC repair happens in 10 to $13 \%$ of the cases. This condition can lead to tethered-cord syndrome with neurological-deterioration, back and leg pain, incontinent bladder, spasticity, change in motor or sensory level in lower extremities, severe scoliosis and other occurrences $^{6,19}$. Multiple biological materials, such as collagen, autologous muscular fascia, muscle flaps and acellular human dermis have been used as a duramater substitutes for reconstruction or duraplasty ${ }^{11,13,14}$. Intrauterine repair success of correction-prone malformations depends on many factors, such as gestational age, stage of disease in utero, the surgical technique used for repair, surgical time, uterine wall injury, amniotic fluid leakage, dissection and suture extension in fetuses. This study compared the effectiveness of two different types of dura-mater 
substitutes, namely HADM and BC, for the repair MMC in fetal sheep using a simplified technique for closure of the defect. An ovine model was chosen because its validity had been previously established ${ }^{20}$. Our study used fetuses with surgically created neural tube defects that were maintained in utero for four weeks to allow the neural tissue injury to occur, simulating the real environment of a human MMC defect. Either HADM or BC was placed over the neural tissue and under the sutured skin to assess their ability to protect the medulla. In the present model, our goal was to protect the medulla from the hostile intra-uterine environment thus avoiding progressive damage and preventing the medulla from adhering to the surrounding tissues which could lead to tethered cord syndrome. We showed that BC was more effective in preventing neural injury and produced less problems related to the corrective surgery than HADM. $\mathrm{BC}$ did not adhere to neural tissue, or cause a giant cell reaction or blood vessels to proliferate at the site of injury. Moreover, the fibroblast layer formed an envelope around the $\mathrm{BC}$ creating a cleavage plane that would most likely be easier to dissect during post-natal surgery. In contrast, HADM was inundated with multiple blood vessels within its layers, adhered to neural tissue and skin, and showed an ingrowth of cells. In addition to its superiority in avoiding neural injury, BC offered other advantages over HADM. We found that BC was easy to handle at surgery and was ready to use without needing any prior preparation. Each film was 10 x $15 \mathrm{~cm}$, a size large enough to allow tailoring to cover the entire lesion found at surgery. On the contrary, HADM was costly, had to be acquired at a specific size, and required a saline warm bath for 30 minutes before use. Similar findings have been reported both in animals as humans ${ }^{17,18,21}$. For example, HADM used for abdominal wall reconstruction in a rabbit model, showed the expected interaction with the host tissue as illustrated by revascularization and skin ingrowth on the material ${ }^{21}$. From our point of view, HADM is not appropriate for the intra-uterine MMC repair. Our findings are concordant with the observations of Farmer et $\mathrm{al}^{6}$ on the correction of MMC in human fetuses. Using the fetal open surgery approach, these authors used HADM in their first cases and found postnatal corrective surgery to be much more difficult, and therefore abandoned its use in subsequent cases. It was also applied as a patch over MMC fetal ovine models, placed in contact with amniotic fluid and not as an interface between the neural tissue and $\operatorname{skin}^{13}$. The authors described wound edge retractions and no "gross" adhesion between cord and patch. However the HADM studies did not involve a comparison to BC and the studies focused on cerebellar herniation and post-natal neurological functions and not on the local effects of these materials on the damaged spinal cord. Two other interface materials (biomatrices) were studied by Eggink et $\mathrm{al}^{22}$, one obtained from small intestinal submucosa and the other from bovine tendon collagen. These biomatrices were used for the acute correction of a neural tube defect induced in sheep. They compared both materials with the simple closure of the skin over the defect using suture. They found no differences in postnatal outcome (hydrocephalus, cerebellar herniation or urinary incontinence) among the three groups. As defect creation and its correction occurred during the same procedure, there was no long term exposure of the neural tissue to the amniotic fluid making difficult to compare their findings with ours. Our histological findings for BCtreated animals were also similar to what has been reported in the literature. BC was used as a dura-mater substitute by Mello et $a^{14}$ in dogs submitted to craniotomies, with encouraging findings. After this, Pedreira et al (2003) ${ }^{16}$ successfully tested BC in rabbit fetuses for MMC repair. Mello et $\mathrm{al}^{14}$ stated that the BC might be dissolved in tissue alkalis, however, during a maximum 270 day period, they found no evidence of $\mathrm{BC}$ digestion or absorption. We believe that this period is enough to keep the exposed neural tissue safely covered throughout gestation. The film detaches from cerebral tissue even after this period, mimicking the duramater ${ }^{14}$. These characteristics guarantee the persistence of the BC throughout gestation without modifications. At birth we propose definitive correction by classic neurosurgical techniques. The fibroblast layer that formed under the $\mathrm{BC}$, in continuity with dura-mater, probably will have the expected effect of avoiding fluid leakage, constituting a "neodura-mater". In our opinion the characteristics and histological findings in our experiment showed that BC avoided the adhesion between the tissues, leading to convenient neural tissue protection during intrauterine period.

\section{Conclusion}

The use of BC appears to be a more effective choice than HADM to for spinal cord protection for the in utero repair of experimental MMC. BC was superior in intraoperative handling and avoiding neural tissue adhesion. This latter feature is an advantage facilitating the removal of BC in the post-natal corrective neurosurgery. Thus, our findings suggest that pre-natal application of BC will protect the medulla from the hostile intra-uterine environment thus avoiding progressive damage and ensuring a greater chance that post-natal surgery will correct MMC.

\section{References}

1. von Koch CS, Compagnone N, Hirose S, Yoder S, Harrison MH, Farmer, DL. Myelomeningocele: characterization of a surgically induced sheep model and its central nervous system similarities and differences to the human disease. Am J Obstet Gynecol. 2005;193:1456-62. 
2. Hutchins GM, Meuli M, Meuli-Simmen C, Jordan MA, Heffez, DS, Blakemore, KJ. Acquired spinal cord injury in human foetuses with myelomeningocele. Pediatr Patol Lab Med. 1996;16:701-12.

3. Pedreira DAL, Valente PR, Abou-Jamra RC, Pelarigo CL, Silva LM, Goldenberg S. A different technique to create a 'myelomeningocele-like' defect in the fetal rabbit. Fetal Diagn Ther. 2002;17:372-6.

4. Meuli M, Meuli-Simmen C, Yingling CD, Hutchins GM, Hoffman KM, Harrison MR, Adzick NS. Creation of myelomeningocele in utero: a model of functional damage from spinal cord exposure in fetal sheep. J Pediatr Surg. 1995;30:1028-33.

5. Meuli M, Meuli-Simmen C, Hutchins GM, Seller MJ, Harrison MR, Adzick NS. The spinal cord lesion in human foetuses with myelomeningocele: Implications for fetal surgery. J Pediatr Surg. 1997;32:448-52.

6. George TM, Fagan LH. Adult tethered cord syndrome in patients with post repair myelomeningocele: an evidencebased outcome study. J Neurosurg. 2005;102:150-6.

7. Sutton LN, Adzick NS, Bilanuik LT, Johnson MP, Crombleholme, TM, Flake AW. Improvement in hindbrain herniation demonstrated by serial fetal MRI following fetal surgery for myelomeningocele. J Am Med Assoc. 1999;282(19):1826-31.

8. Bruner JP, Tulipan N, Paschall RL, Boehm FH, Walsh WF, Silva SR, Hernanz-Schulman M, Lowe LH, Reed GW. Fetal surgery for myelomeningocele and the incidence of shunt-dependent hydrocephalus. J Am Med Assoc. 1999;282:1819-25.

9. Tulipan N, Sutton LN, Bruner JP, Cohen BM, Johnson M, Adzick NS. The effect of intrauterine myelomeningocele repair on the incidence of shunt-dependent hydrocephalus. Pediatr Neurosurg. 2003;38:27-33.

10. Farmer DL, von Koch CS, Peacock WJ, Danielpour M, Gupta N, Lee H, Harrison MR. In utero repair of myelomeningocele. Arch Surg. 2003;138:872-8.

11. Warren WL, Medary MB, Dureza CD, Bellotte jB, Flannagan PP, Oh MY, Fukushima T. Dural repair using acellular human dermis: experience with 200 cases: technique assessment. Neurosurgery. 2000;46:1391-6.

12. Kapfer SA, Keshen TH. The use of human acellular dermis in the operative management of giant omphalocele. $\mathrm{J}$ Pediatr Surg. 2006;41:216-20.
13. Paek BW, Farmer D, Wilkinson C, Craig TA, Peacock W, Harrison MR, Jennings RW. Hindbrain herniation develops in surgically created myelomeningocele but is absent after repair in fetal lambs. Am J Obstet Gynecol. 2000;183:1119-23.

14. Mello LR, Feltrin, LT, Fontes Neto PT, Ferraz, FAP. Duraplasty with biosynthetic cellulose: an experimental study. J Neurosurg. 1997;86:143-50.

15. Mello LR, Feltrin, LT, Selbach R, Macedo Jr G, Saputz C, Haas LJ. Uso da cellulose liofilizada em lesões de nervos periféricos com perda de substância. Arq Neuropsiquiatr. 2001;59(2-B):372-9.

16. Pedreira DAL, Valente PR, Abou-Jamra RC, Pelarigo CL, Silva LM, Goldenberg S. Successfull technique to correct a myelomeningocele-like defect in the fetal rabbit. Fetal Diagn Ther. 2003;18:201-6.

17. Sclafani AP, Romo T, Jacono AA, McCormick S, Cocker R, Parker A. Evaluation of acellular dermal graft in sheet (AlloDerm) and Injectable (Micronized AlloDerm) forms for soft tissue augmentation: clinical observations and histological analysis. Arch Facial Plast Surg. 2000;2(2):130-6.

18. Sclafani AP, Romo T, Jacono AA, McCormick S, Cocker R, Parker A. Evaluation of acellular dermal graft (AlloDerm) sheet for soft tissue augmentation: a 1-year follow-up of clinical observations and histological findings. Arch Facial Plast Surg. 2001;3(2):101-3.

19. Mazzola CA, Albright AL, Sutton LN, Tuite GF, Hamilton RL, Pollack IF. Dermoid inclusion cysts and early spinal cord tethering after fetal surgery for myelomeningocele. N Engl Med. 2002;347(4):256-9.

20. Pedreira DAL, Sanchez e Oliveira RC, Valente PR, AbouJamra RC; Araújo A, Saldiva PH. Validação do feto de ovino como modelo experimental de meningomielocele: estudo piloto. Einstein. 2006;4(4):251-5.

21. Menon NG, Rodriguez ED, Byrnes CK, Girotto JA, Goldberg NH, Silverman RP. Revascularization of human acellular dermis in full-thickness abdominal wall reconstruction in the rabbit model. Ann Plast Surg. 2003;50:523-7.

22. Eggkin AJ, Roelofs LAJ, Feitz WFJ, Wijnen RMH, Mullaart RA, Grotenhuis JA, Van Kuppevelt TH, Lammens MMY, Crevels AJ, Hanssen A, Van Den Berg PP. In utero repair of an experimental neural tube defect in a chronic sheep model using biomatrices. Fetal Diagn Ther. 2005;20:335-40.

\section{Correspondence:}

Rita de Cássia Sanchez Oliveira

Rua do Rocio, 423/CJ 312

04552-000 São Paulo - SP Brazil

Phone/Fax: (55-11)3846-2409 / 3846-7335

ritasanches@einstein.br/tagides@uol.com.br
Conflict of interest: none

Financial source: FAPESP (Proc. $n^{\circ}$ 03/07237-4)

Received: January 26, 2007

Review: February 23, 2007

Accepted: March 20, 2007

\section{How to cite this article}

Oliveira RCS, Valente PR, Abou-Jamra RC, Araújo A, Saldiva PH, Pedreira DAL. Biosynthetic cellulose induces the formation of a "neoduramater" following pre-natal correction of meningomyelocele in fetal sheep. Acta Cir Bras. [serial on the Internet] 2007 May-June;22(3). Available from URL: http://www.scielo.br/acb 